\title{
Mortality due to congenital heart disease in Pernambuco from 1996 to 2016
}

\author{
(D) Jõ̃o Victor Batista Cabral ${ }^{1}$ \\ (D) Aline Luzia Sampaio Guimarães ${ }^{2}$ \\ (iD) Dário Celestino Sobral Filho ${ }^{1}$ \\ (iD) Ana Célia Oliveira dos Santos ${ }^{1}$
}

1. Programa de Pós-graduação em Ciências da Saúde da Faculdade de Ciências Médicas e Instituto de Ciências Biológicas - Universidade de Pernambuco, Recife,

2. Residência Multiprofissional em Saúde Coletiva. Prefeitura Municipal de Recife, Recife, PE, Brasil

\section{SUMMARY}

BACKGROUND: To determine the magnitude and temporal trends of deaths due to congenital heart disease (CHD) in Pernambuco between 1996 and 2016.

METHODS: This was an ecological, time-series study, involving all cases of deaths from congenital cardiovascular malformations in the state of Pernambuco, from 1996 to 2016, using data from DATASUS, SINASC and SIM.

RESULTS: There were 3,584 deaths from congenital cardiovascular malformations amongst individuals aged 0 to 14 years, of which $81.94 \%$ were concentrated in children aged under one year. The infant mortality rate (IMR) presented a linear growth trend of 0.4645 per year $(p<0.01)$. The cause-of-death code Q24 (other congenital malformations of the heart) was present in $72.54 \%$ of the death records and $48.17 \%$ of the deaths occurred in infants aged between 28 and 364 days of life. The highest occurrence of deaths was identified in children with low birth weight (500 and 1,499g), male, premature, children of mothers without schooling, in deliveries at home ( $p<0.05)$.

CONCLUSIONS: Congenital heart disease still represents a public health problem as a cause of death, particularly in the first year of life, with IMR in a linear growth trend. Deaths from CHD were more prevalent in male children, born prematurely, with low birth weight, born to mothers with low schooling and deliveries without medical care.

KEYWORDS: Infant mortality. Heart diseases. Congenital abnormalities.

\section{INTRODUCTION}

Congenital heart diseases (CHD) are a frequent anomaly with an estimated incidence ranging from 8 to 10 per 1,000 live births and associated with a high mortality rate, significant social and health care $\operatorname{costs}^{1,2}$. CHD is a broad clinical spectrum, ranging from asymptomatic to complex and potentially fatal defects $^{1-3}$.
Approximately four million neonatal deaths occur each year and it is estimated that $7 \%$ are related to some type of CHD. It should be noted that without intervention, $30 \%$ of infants presenting with heart disease will not survive the first year of life $\mathrm{e}^{4}$. CHD is the leading cause of death in neonates, the ninth cause of death in infants aged under 1 year, the eighth between

DATE OF SUBMISSION: 30-Dec-2019

DATE OF ACCEPTANCE: 19-Jan-2020

CORRESPONDING AUTHOR: Ana Célia dos Santos

Rua Arnobio Marques, S/N - Santo Amaro, Recife, Pernambuco - Brasil - 50100-130

Tel:558131833311 - Fax: 558131833301

E-mail: ana.oliveira@upe.br 
1 and 9 years, and seventh in children aged between 10 and $14^{5,6}$. In the Brazilian state of Pernambuco, between 1979 and 2003, congenital malformations of the cardiovascular system accounted for $41 \%$ of the deaths among children under one year with congenital anomalies ${ }^{7}$.

The impact of congenital anomalies on infant mortality rates is dependent on several factors, such as the quality, availability, and access to surgical treatment and primary healthcare. Thus, knowing the mortality profile of CHD is important to understand its impacts on infant health and as an indicator for primary and tertiary levels of child care. The aim of this study was to determine the magnitude and temporal trends of deaths from cardiovascular congenital malformations in Pernambuco, between 1996 and 2016.

\section{METHODS}

This was an ecological, time-series study, involving all cases of death due to congenital cardiovascular malformations in the state of Pernambuco, Brasil, between 1996 and 2016, with data collection between January and February 2019. The sample was composed of all cases of death in the population aged between 0 (zero) and 14 years, with the cause of death defined as congenital by the International Classification of Diseases (ICD 10), codes Q20 to Q28 ${ }^{8}$.

All cases of death from CHD were listed by accessing data from the Informatics Department of the Brazilian Unified Health System (DATASUS), the Live Birth Information System (SINASC), and the Mortality Information System (SIM), through the TABNET website, and data analysis was conducted in R 3.1.1 ${ }^{\circledR}$. The following variables were analyzed: deaths of infants/ children aged from 0 to 14 years due to ICD-10 codes Q20 to Q28, infant death by: age group, gender, birth weight, maternal education, length of pregnancy, place of birth, and calculating the infant mortality rate (IMR).

Frequency distribution matrices were used to calculate the means and their respective standard deviations for the quantitative variables. All data presented normal distribution with the Kolmogorov-Smirnov or Shapiro tests, and the homogeneity of variances was verified with the Bartlett test. The Anova and Tukey ad hoc tests were performed to assess the differences between the mean values of three or more data sets. T-tests enabled a comparison between the mean values of two data sets. A significant difference was considered for $\mathrm{p} \leq 0.05$. An assessment of the trends of infant mortality data was made by linear regression.

The study was approved by the Pernambuco State Secretariat for Health and by the Research Ethics Committee at the Oswaldo Cruz Complex/PROCAPE, in accordance with Report $\mathrm{N}^{\circ}$ 3.025.594 and CAAE: 84512018.1.0000.5192, complying with Resolution $\mathrm{N}^{\circ}$ 466/2012 of the National Health Council.

FIGURE 1. DEATHS DUE TO CONGENITAL CARDIOVASCULAR MALFORMATIONS X BIRTH WEIGHT. PERNAMBUCO, 1996 TO 2016

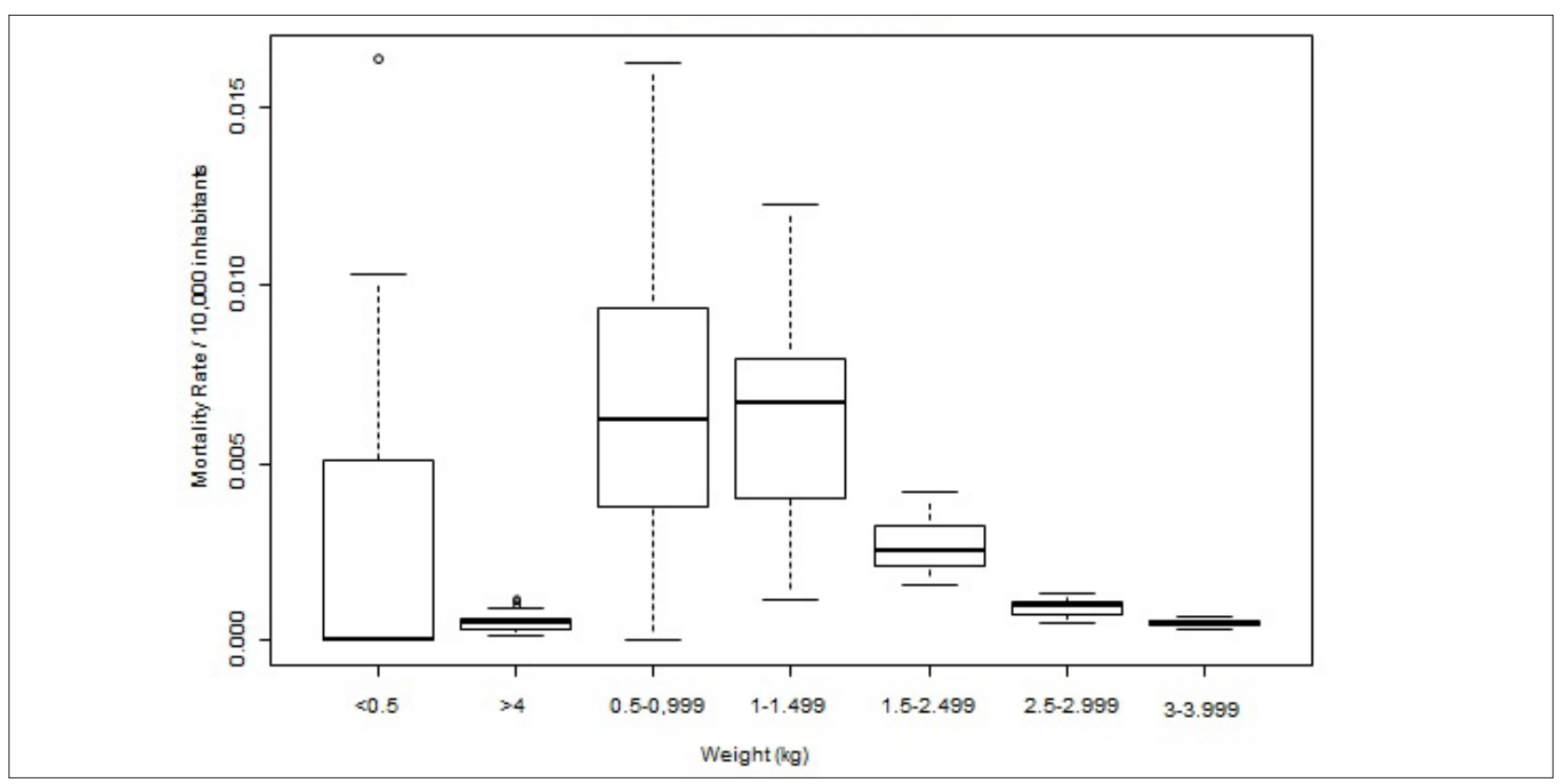


TABLE 1. OVERALL CAUSE MORTALITY Q X AGE (YEARS AND DAYS). PERNAMBUCO, 1996 TO 2016.

\begin{tabular}{|c|c|c|c|c|c|}
\hline \multirow{2}{*}{$\begin{array}{l}\text { Code } \\
\text { ICD-10* }\end{array}$} & \multicolumn{4}{|c|}{ Age (years) } & \multirow[b]{2}{*}{$n(\%)$} \\
\hline & $\begin{array}{l}<1 \\
\text { year }\end{array}$ & \begin{tabular}{|l|}
1 a 4 \\
years
\end{tabular} & $\begin{array}{l}5 \text { a } 9 \\
\text { years }\end{array}$ & $\begin{array}{l}10 \text { a } 14 \\
\text { years }\end{array}$ & \\
\hline Q20 & 128 & 12 & 4 & 1 & $145(4.04)$ \\
\hline Q21 & 278 & 83 & 23 & 14 & $398(11.10)$ \\
\hline Q22 & 48 & 9 & 5 & 4 & $66(1.84)$ \\
\hline Q23 & 51 & 3 & 8 & 2 & 64 (1.78) \\
\hline Q24 & 2170 & 301 & 80 & 42 & $2593(72.34)$ \\
\hline Q25 & 210 & 10 & 6 & 4 & $230(6.41)$ \\
\hline Q26 & 5 & 0 & 0 & 0 & $5(0.13)$ \\
\hline Q27 & 13 & 1 & 2 & 6 & $22(0.61)$ \\
\hline Q28 & 34 & 11 & 9 & 7 & $61(1.70)$ \\
\hline TOTAL & 2937 & 430 & 137 & 80 & $3584(100)$ \\
\hline \multirow{2}{*}{$\begin{array}{l}\text { Code } \\
\text { ICD-10 }\end{array}$} & \multicolumn{4}{|c|}{ Age (days) } & \multirow[b]{2}{*}{$n(\%)$} \\
\hline & $\begin{array}{l}0 \text { a } 6 \\
\text { days }\end{array}$ & $\begin{array}{l}7 \text { a } 27 \\
\text { days }\end{array}$ & $\begin{array}{l}28 \text { a } 364 \\
\text { days }\end{array}$ & Unknown & \\
\hline Q20 & 21 & 42 & 65 & 0 & $128(4.35)$ \\
\hline Q21 & 53 & 43 & 181 & 1 & $278(9.46)$ \\
\hline Q22 & 14 & 9 & 25 & 0 & 48 (1.63) \\
\hline Q23 & 14 & 14 & 23 & 0 & 51 (1.73) \\
\hline Q24 & 716 & 439 & 1014 & 1 & $2170(73.88)$ \\
\hline Q25 & 58 & 72 & 80 & 0 & $210(7.15)$ \\
\hline Q26 & 2 & 0 & 3 & 0 & $5(0.17)$ \\
\hline Q27 & 4 & 3 & 6 & 0 & $13(0.44)$ \\
\hline Q28 & 10 & 6 & 18 & 0 & $34(1.15)$ \\
\hline$n$ & \multirow{2}{*}{$\begin{array}{l}892 \\
(30.37)\end{array}$} & \multirow{2}{*}{\begin{tabular}{|l}
628 \\
$(21.38)$
\end{tabular}} & \multirow{2}{*}{\begin{tabular}{|l}
1415 \\
$(48.17)$ \\
\end{tabular}} & \multirow{2}{*}{$\begin{array}{l}290 \\
(0.06)\end{array}$} & 2937 \\
\hline$(\%)$ & & & & & $(100)$ \\
\hline
\end{tabular}

ICD-10: International Classification of Diseases and Related Health Problems, 10th Revision

\section{RESULTS}

The study included all cases of death from CHD amongst infants/children aged between 0 and 14 years, from 1996 to 2016, totaling 3.854 cases, of which 2.937 occurred in infants aged under one year. Thus, Table 1 presents data from the general population up to 14 years of age. In Figure 1 and Table 2, we decided to present data from the population aged one year and under, thereby representing $81.94 \%$ of all deaths.

With regard to the number of deaths of infants/children aged between 0 and 14 years of age due to CHD, there was a predominance in the group $<1$ year, corresponding to 2.937 of total deaths, and ICD-10 code Q24 (other congenital malformations of the heart) was the most frequent in all ages, $72.34 \%(\mathrm{n}=2.593)$, of all deaths (Table 1).

In infants aged under one year, the ICD-10 code Q24 represented the majority of cases of death, with $73.88 \%$
TABLE 2. DEATHS DUE TO CONGENITAL CARDIOVASCULAR MALFORMATIONS VERSUS MATERNAL CHARACTERISTICS AND PLACE OF DELIVERY. PERNAMBUCO, 1996 TO 2016.

\begin{tabular}{|c|c|c|c|}
\hline $\begin{array}{l}\text { Maternal } \\
\text { Education } \\
\text { (in years) }\end{array}$ & $\begin{array}{l}\mathrm{n} \\
\text { (per year) }\end{array}$ & $\begin{array}{l}\mathrm{N} \\
\text { (per year) }\end{array}$ & $\begin{array}{l}M^{*} \text { (mortality rate per } \\
10000 \text { inhabitants) } \\
\pm D P\end{array}$ \\
\hline $\mathrm{O}$ (no schooling) & 10.1 & 10226 & $9.9 \pm 4.7^{b}$ \\
\hline $1-3$ & 12.1 & 16136 & $7.5 \pm 6.1^{a}$ \\
\hline $4-7 s$ & 34.2 & 41956 & $8.1 \pm 1.6^{a}$ \\
\hline $8-11$ & 35.9 & 46129 & $7.8 \pm 2.1^{a}$ \\
\hline$\geq 12$ & 12.1 & 14486 & $8.4 \pm 4.3^{a}$ \\
\hline $\begin{array}{l}\text { Gestational } \\
\text { age (weeks) }\end{array}$ & $\begin{array}{l}\mathrm{n} \\
\text { (per year) }\end{array}$ & $\begin{array}{l}\mathrm{N} \\
\text { (per year) }\end{array}$ & $\begin{array}{l}\text { MR* (mortality rate per } \\
10000 \text { inhabitants) } \\
\pm \text { DP }\end{array}$ \\
\hline$<22$ & 3.0 & 109 & $279.5 \pm 7.3^{b}$ \\
\hline 22 a 27 & 3.2 & 611 & $53.0 \pm 2.3^{a}$ \\
\hline 28 a 31 & 6.0 & 1156 & $51.5 \pm 2.9^{a}$ \\
\hline 32 a 36 & 18.7 & 9219 & $20.3 \pm 8.8^{a}$ \\
\hline 37 a 41 & 75.2 & 132999 & $5.7 \pm 1.6^{a}$ \\
\hline 42 & 2.1 & 3319 & $6.3 \pm 1.4^{a}$ \\
\hline Place of delivery & $\begin{array}{l}\mathrm{n} \\
\text { (per year) }\end{array}$ & $\begin{array}{l}\mathrm{N} \\
\text { (per year) }\end{array}$ & $\begin{array}{l}\mathrm{MR}^{*} \text { (mortality rate per } \\
10000 \text { inhabitants) } \\
\pm \mathrm{DP}\end{array}$ \\
\hline $\begin{array}{l}\text { Health services } \\
\text { for child birth care }\end{array}$ & 131.9 & 146030 & $9.0 \pm 5.0^{a}$ \\
\hline $\begin{array}{l}\text { Other health } \\
\text { service }\end{array}$ & 0.9 & 1350 & $6.7 \pm 1.1^{\mathrm{a}}$ \\
\hline At home & 5.4 & 1344 & $40.4 \pm 2.5^{b}$ \\
\hline
\end{tabular}

$\mathrm{n}=$ mean number of deaths associated with congenital cardiovascular malformations during the study period; $\mathrm{N}=$ mean of live births in the study period; $M R=$ mean mortality rate associated with congenital cardiovascular malformations. SD = standard deviation. "Means followed by the same letter do not differ statistically from each other
by the Tukey test, at $5 \%$ probability..

$(\mathrm{n}=2.170)$. It should be noted that $48.17 \%(\mathrm{n}=1.415)$ of deaths occurred in infants aged older than 28 days and younger than 364 days. However, 30.37\% $(\mathrm{n}=892)$ occurred early in infants aged from 0 to 6 days (Table 1).

The IMR presented heterogeneous results. The lowest rate occurred in 2001 (6.64) and the highest in 2009 (11.49). However, a general increase may be observed. The IMR regression demonstrated a linear growth trend with an increase of $0.4645 /$ year $(p<0.001)$.

A significant difference (ANOVA, $F=21.59$, $\mathrm{p}<0.0001)$ was observed in the mean values of the mortality rates of infants born weighing between $500 \mathrm{~g}$ and $1.499 \mathrm{~g}$ (Figure 1) and in male infants $(\mathrm{t}$-test, $\mathrm{t}=2.11, \mathrm{p}<0.05)$. A significant difference was observed in the occurrence of death amongst those born to mothers with no schooling (ANOVA, $\mathrm{F}=6.97, \mathrm{p}<0.001$ ), whose gestation had been less than 
22 weeks (ANOVA, $\mathrm{F}=7.81, \mathrm{p}<0.0001$ ), and at home delivery (ANOVA, $\mathrm{F}=12.09, \mathrm{p}<0.0001)$ (Table 2).

\section{DISCUSSION}

There was a predominance of deaths from congenital malformations of the heart in the group $<1$ year, and the ICD-10 code Q24 was the most frequent cause of death at all ages. It should be emphasized that the data were taken from the information system and accurate diagnoses require cardiology staff, in specific services. Matos $^{9}$ reported that CHD was the leading cause of mortality amongst congenital malformations, accounting for $80 \%$ of deaths in infants aged under one year. Most CHD contributes to the occurrence of deaths since the anatomical and clinical conditions presented are often incompatible with life and are extremely dependent on advanced, appropriate medical-hospital care in order to survive ${ }^{10}$.

Lopes et al. ${ }^{11}$ and Brum et al. ${ }^{12}$ highlight that CHD is associated with a higher occurrence of fetal deaths, since it is present in up to $85 \%$ of autopsy findings, and is an outstanding major factor for causing cardiac arrest during the first two years of life. It should be highlighted that the number of deaths related to CHD is officially lower than in fact it should be. Underreporting in Brasil remains a constant reality since newborns often leave hospital clinically well, and on arrival at home begin to degenerate, thereby dying without hospital records registering the true cause of death ${ }^{10,12}$.

A study in Rio de Janeiro observed that the highest proportion of mortality was through unspecified congenital malformations of the heart ${ }^{13}$. These results would suggest poor access to prenatal care or to CHD diagnosis services at birth, which hinders or even prevents any timely treatment ${ }^{13}$.

The linear regression of the evolution of the IMR demonstrated a growing trend. In Brasil, between 2003 and 2013 the IMR from congenital malformations of the heart was 1.03, and the Midwest region of the country presented the highest rate (1.25) and the Northeast the lowest $(0.93)^{10}$. Braga et al. ${ }^{14}$ analyzed the mortality trend from CHD in Brasil and observed that overall there was a fluctuation throughout the period with a decrease observed during the last year. Matos $^{9}$, in the state of Bahia between 2003 and 2013, reported that the IMR presented a progressive increase within the pediatric age group.

The temporal patterns of CHD present a certain degree of heterogeneity. In Canada and European countries, mortality rates due to CHD have decreased, particularly in infants aged under one year ${ }^{15,16}$. In contrast to previous studies, a large-sample, population-based study on CHD, using echocardiography, was conducted in China finding a CHD prevalence of $22.9 \%$, in two years of study ${ }^{17}$; in Mexico, infant mortality from CHD increased 24.8\% from 1998 to 2013. It should be highlighted that hypotheses have been raised to justify this increase in mortality rates, for example, the improved diagnosis of CHD and a greater number of perinatal necropsies ${ }^{18}$.

Arruda et al. ${ }^{7}$ assessed mortality from congenital malformations in Pernambuco from 1993 to 2003, and demonstrated that these accounted for $41 \%$ of all deaths, and that there was an increasing trend in coefficients of early neonatal $(p=0.003)$, perinatal $(p=0.005)$, neonatal $(p=0.0007)$, and infants aged under one year $(\mathrm{p}=0.02)$ mortality.

In a study by Torres-Cosme et al. ${ }^{18}$ conducted in Mexico, infant mortality from CHD increased by $24.8 \%$ from 1998 to 2013 (114.4 to 146.4/100,000 live births). This finding runs counter to overall global mortality, since the number of deaths in infants aged under five decreased by 47\% from 1990 to 2015, from 90.6 to 42.5 deaths per 1,000 live births. Efficient strategies and actions aimed at reducing diarrhea, respiratory infections and an increase in the development and success of vaccination may also justify this fact.

It should be emphasized that mortality due to CHD varies when assessed within global rates ${ }^{19}$. Industrially limited countries or those classified as "developing nations", which still suffer from poor access to healthcare, present significantly higher mortality rates than those of developed countries ${ }^{10}$. High mortality rates due to CHD result from poor or inadequate diagnostic services during the prenatal period, thereby leading to ineffective treatments and frequent deaths. Early, accurate diagnosis is a prerequisite for a more favorable prognosis and for establishing effective healthcare.

In an analysis of the causes of death during the first 24 hours of life, Torres-Cosme et al..$^{18}$ reported that around $90 \%$ of cases did not have a specific diagnosis, which is of great concern. It is argued that newborns with a known prenatal diagnosis of CHD were significantly less likely to die before cardiac surgery when compared to those diagnosed postpartum $(\mathrm{OR}=0.26$; 95\% CI: 0.08-0.84).

This result is corroborated by Matos ${ }^{9}$, who reported that the ICD-10 code Q24 was present in $75.7 \%$ of the records, which demonstrated an inaccuracy in the 
diagnosis of causa mortis pathology. This may have been due to a lack of knowledge regarding the large number of congenital heart defects by the doctors who confirmed the deaths and signed the death certificates or possibly even by the absence of an autopsy. We confirmed that a significant portion of the deaths occurred during the first days of life. Similar results were found in the state of Bahia, where $48 \%$ of deaths occurred in the post-neonatal period (28 to 364 days), followed by early neonatal, from 0 to 6 days, corresponding to $34 \%$ of total deaths 9 . The first week of life is seen as a critical period during which a significant number of CHD deaths occur. Special attention should be given to this phase, understanding that it is necessary to enable specialized health care.

Birth weight is an important factor for the occurrence of events in newborns. This study has demonstrated a statistical significance for mortality in children weighing between 500 and 1,499g. Lopes et al. ${ }^{11}$ described that a birth weight $<2,500 \mathrm{~g}$ was a risk factor for death in newborns with CHD (RR: 2.33; 95\% CI 1.26-4.29; $p$ 0.0068), which was also reported by Brum et al..$^{12}$ (26.7\% of deaths, p 0.015), Aquino et al. ${ }^{20}$, and Carvalho et al. ${ }^{21}$.

Araújo et al. ${ }^{22}$ highlighted that the mortality risk for male newborns was 4.16 times higher than for girls. Furthermore, they also emphasized that early neonatal mortality was higher in males for all weight ranges.

There are very few studies that seek to associate mortality from CHD with levels of education. Araújo et al. ${ }^{22}$ sought to describe the profile of CHD in the state of Paraiba between 2001 and 2011 and discovered that the parents of a significant proportion of CHD cases had received little education. The authors emphasized that while there was no direct biologically responsible mechanism, it is crucial to take into account that educational attainment is closely linked to obtaining information and a higher purchasing power. These factors are crucial for good prenatal care and thus for developing an effective follow-up in order to avoid a variety of risk factors detrimental to the fetus.

Aquino et al. ${ }^{20}$ and Carvalho et al. ${ }^{21}$ aimed to analyze the risk factors associated with perinatal mortality in Recife-PE, observed that if a mother had attended school for less than four years $(\mathrm{OR}=1.78)$, this was a risk factor for perinatal mortality.

Furthermore, according to Aquino et al. ${ }^{20}$, it was observed that prematurity $(\mathrm{OR}=18.23)$ remained an important risk factor for perinatal mortality since this variable was most strongly associated with perinatal death. Low birth weight and length of gestation should not be studied in isolation, but as mediators through which determinants act, such as maternal education, socioeconomic conditions, biological characteristics, and life habits of the mother, as well as access to health services during pregnancy.

In Caxias do Sul (Rio Grande do Sul), it was observed that the risk of mortality in premature infants $(<37$ weeks) was five times higher when compared to the 39-41-week group, thereby demonstrating a marked increase in mortality as the gestational age decreases ${ }^{23}$.

With regard to the place of delivery, Torres-Cosme et al. ${ }^{18}$ reported that while hospital births presented the lowest CHD mortality rates, at home births presented the highest, comprising $22.3 \%$ of the total number of deaths. Homebirth is a risk factor for death with the presence of $\mathrm{CHD}(\mathrm{OR}=95 \% \mathrm{CI}=6.34 ; 5.49-7.32)$. This fact leads us to emphasize possible weaknesses in primary health care, particularly with regard to the conditions of delivery.

\section{CONCLUSIONS}

In the state of Pernambuco, the CCM was responsible for 3,584 deaths from 1996 to 2016, which occurred predominantly in children under one year. The IMR showed a linear growth trend. The ICD-10 Q24 cause-of-death code was present in most death certificates. The general characteristics that showed statistical significance for death were prematurity, low birth weight, male babies born to mothers with no education, with home delivery.

\section{Acknowledgments}

The present study was conducted with support from the Coordination for the Improvement of Higher Education Personnel - Brasil (CAPES) - Funding Code 001 - CAPES, ordinance No. 206, September 4, 2018.

\section{Author's Contribution}

João Victor Batista Cabral: participated in all stages of research, from the preparation of the project, as well as data collection and analysis, to the drafting of the paper. Aline Luzia Sampaio Guimarães: participated in data collection. Dário Celestino Sobral Filho: participated in the critical review and drafting of the work. Ana Célia Oliveira dos Santos: coordinated all stages of research, from the preparation of the project, as well as data collection and analysis, to the drafting of the paper. 


\section{RESUMO}

OBJETIVO: Determinar a magnitude e tendência temporal dos óbitos por doenças cardiovasculares congênitas (DCC) em Pernambuco entre 1996 e 2016.

MÉTODOS: Trata-se de um estudo ecológico, de série temporal, com todos os casos de óbitos por doenças cardiovasculares congênitas no estado de Pernambuco, entre 1996 e 2016, por meio dos dados do Datasus, Sinasc e SIM.

RESULTADOS: Ocorreram 3.584 óbitos por DCC entre indivíduos de 0 a 14 anos de idade, dos quais 81,94\% foram concentrados em crianças menores de 1 ano de idade. A taxa de mortalidade infantil apresentou tendência linear de crescimento de 0,4645 por ano $(p<0,01)$. A causa Q24 (outras malformações congênitas do coração) esteve presente em $72,54 \%$ dos registros de óbitos e $48,17 \%$ dos óbitos ocorreram na faixa etária de 28 a 364 dias de vida. Maior ocorrência de óbitos foi identificada entre os nascidos com peso entre 500 e 1.499 g, do sexo masculino, pré-termos, filhos de mães sem escolaridade e em partos domiciliares ( $p<0,05)$.

CONCLUSÕES: As cardiopatias congênitas ainda representam um problema de saúde pública como causa de mortalidade, especialmente no primeiro ano de vida. A taxa de mortalidade por DCC apresentou tendência linear de crescimento. As características gerais demonstraram significância estatística para óbitos entre crianças prematuras, com baixo peso, do sexo masculino, nascidas de mães sem escolaridade e em partos domiciliares.

PALAVRAS-CHAVE: Mortalidade infantil. Cardiopatias. Anormalidades congênitas.

\section{REFERENCES}

1. Hoffman JI, Kaplan S. The incidence of congenital heart disease. J Am Coll Cardiol. 2002;39(12):1890-900.

2. Leite DL, Miziara H, Veloso M. Malformações cardíacas congênitas em necropsias pediátricas: características, associações e prevalência. Arq Bras Cardiol. 2010;94(3):294-9.

3. Santos BGM, Moraes NS, Ibrahim MAR, Santos IM, Santos CS. Correção cirúrgica de cardiopatias congênitas em recém nascido. Insuf Card. 2012;7(4):184-9.

4. Grassi MS, Jacob CMA, Kulikowski LD, Pastorino AC, Dutra RL, Miura N, et al. Congenital heart disease as a warning sign for the diagnosis of the 22q11.2 deletion. Arq Bras Cardiol. 2014;103(5):382-90.

5. Baltaxe $E$, Zarante I. Prevalence of congenital heart disease in 44,985 newborns in Colombia. Arch Cardiol Mex. 2006;76(3):263-8.

6. Tassinari S, Martínez-Vernaza S, Erazo-Morera N, Pinzón-Arciniegas MC, Gracia G, Zarante I. Epidemiology of congenital heart diseases in Bogotá, Colombia, from 2001 to 2014: improved surveillance or increased prevalence? Biomedica. 2018;38(0):148-55.

7. Arruda TAM, Amorim MMR, Souza ASR. Mortalidade determinada por anomalias congênitas em Pernambuco, Brasil, de 1993 a 2003. Rev Assoc Med Bras. 2008;54(2):122-6.

8. World Health Organization. International classification of diseases and related health problems, $10^{\text {th }}$ revision. Geneva: World Health Organization; 2018. [cited 2019 Nov 20]. Available from: http://www.who.int/ classifications/icd/en/

9. Matos MB. Mortalidade por cardiopatias congênitas no estado da Bahia, Brasil, de 2003 a 2013 [Monografia]. Salvador: Universidade Federal da Bahia;2016.

10. Soares AM. Mortality for critical congenital heart diseases and associated risk factors in newborns. A cohort study. Arq Bras Cardiol. 2018;111(5):674-5.

11. Lopes SAVA, Guimarães ICB, Costa SFO, Acosta AX, Sandes KA, Mendes CMC. Mortality for critical congenital heart diseases and associated risk factors in newborns. A cohort study. Arq Bras Cardiol. 2018;111(5):666-73.

12. Brum CA, Stein AT, Pellanda LC. Infant mortality in Novo Hamburgo: associated factors and cardiovascular causes. Arq Bras Cardiol. 2015;104(4):257-65.
13. Salim TR, Soares GP, Klein CH, Oliveira GMM. Mortality from circulatory system diseases and malformations in children in the state of Rio de Janeiro. Arq Bras Cardiol. 2016;106(6):464-73

14. Braga DC, Saccol MP, Conte TA, Goldmeier R, Pereira RW. Evolução da mortalidade por cardiopatias congênitas no Brasil: um estudo ecológico. J Health Sci Inst. 2017;35(2):105-7.

15. Ionescu-Ittu R, Marelli AJ, Mackie AS, Pilote L. Prevalence of severe congenital heart disease after folic acid fortification of grain products: time trend analysis in Quebec, Canada. BMJ. 2009;338:b1673.

16. Khoshnood B, Loane M, Garne E, Addor MC, Arriola L, Bakker M, et al. Recent decrease in the prevalence of congenital heart defects in Europe. Pediatr. 2013;162(1):108-13. e2.

17. Sun PF, Ding GC, Zhang MY, He SN, Gao Y, Wang JH. Prevalence of congenital heart disease among infants from 2012 to 2014 in Langfang, China. Chin Med J (Engl). 2017;130(9):1069-73.

18. Torres-Cosme JL, Rolón-Porras C, Aguinaga-Ríos M, Acosta-Granado PM, Reyes-Muñoz E, Murguía-Peniche T. Mortality from congenital heart disease in Mexico: a problem on the rise. PLoS One. 2016;11(3):e0150422.

19. Campos DA, Peixoto MSRM, Medeiros BGS, Lucena VS. Fatores genéticos: prevalência de mortalidade neonatal e anomalias congênitas. Biofarm. 2017;13(2):1-10.

20. Aquino TA, Guimarães M|B, Sarinho SW, Ferreira LOC. Fatores de risco para a mortalidade perinatal no Recife, Pernambuco, Brasil, 2003. Cad Saude Publica. 2007;23(12):2853-61.

21. Carvalho PI, Pereira PMH, Frias PG, Figueiroa JN. Fatores de risco para mortalidade neonatal. Epidemiol Serv Saúde. 2007;16(3):185-94.

22 Araújo JSS, Régis CT, Gomes RGS, Silva CS, Abath CMB, Mourato FA, et al. Cardiopatia congênita no nordeste brasileiro: 10 anos consecutivos registrados no Estado da Paraíba, Brasil. Rev Bras Cardiol. 2014;27(1):13-9.

23. Araújo BF, Bozzetti MC, Tanaka ACA. Mortalidade neonatal precoce no município de Caxias do Sul: um estudo de coorte. I Pediatr. 2000;76(763):200-6. 